\title{
Correction to: Rent seeking as an evolving process: the case of the Ancien Régime
}

\author{
Robert B. Ekelund Jr. ${ }^{1} \cdot$ Mark Thornton ${ }^{1,2}$
}

Published online: 24 July 2019

(c) Springer Science+Business Media, LLC, part of Springer Nature 2019

\section{Correction to: Public Choice https://doi.org/10.1007/s11127-019-00674-8}

The original version of this article was published with an erroneous version of the Acknowledgements. Please find in this document the correct version of the Acknowledgements that should be regarded as final version by the reader.

Acknowledgements We are deeply grateful to Richard Ault, George Ford, Phil Gramm, Bob Hébert and Ralph Kingston and to an anonymous reviewer and to the editors of this journal for excellent comments on earlier versions of this paper. We also thank Kathy White for technical support. We dedicate this paper to the late Bob Tollison who is always with us in spirit. Naturally the usual caveat applies.

Publisher's Note Springer Nature remains neutral with regard to jurisdictional claims in published maps and institutional affiliations.

The original article can be found online at https://doi.org/10.1007/s11127-019-00674-8.

Robert B. Ekelund Jr.

bobekelund@prodigy.net

1 Auburn University, Auburn, AL, USA

2 Ludwig von Mises Institute, Auburn, AL, USA 